\title{
Revisiting The Household's Savings Function in Karak, Pakistan
}

\author{
Asmatullah $^{1}$, Dr. Bashir Ahmad Khiliji ${ }^{2}$, Dr. Syed Waqar Hussain ${ }^{3}$, \\ Dr. M. Khalid Mughal ${ }^{4}$
}

\begin{abstract}
The present study was undertaken in Karak in 2011 to investigate household's savings behaviors in rural areas. A sample of 100 respondents was randomly selected and data was gathered through questionnaires. The pilot study was undertaken on 25 questionnaires to identify problems with our questionnaire and sampling techniques. During the pilot study, we observed that some of the respondents were reluctant to answer some key questions pertaining to income and consumption, for instance, and some other had problems with filling questionnaire which induced us for certain modifications. The data was analyzed using various forms of regressions while particular care was exercise to the underlying assumptions and data distribution. The techniques of estimations used were Ordinary Least Square (OLS) and Weighted Least Square (WLS). Our key conclusion is the rejection of common perception that lack of education in rural areas doesn't motivate household to save more. Rather, the conclusion, on the basis of empirical data, reached by the study found that low banking network, sensitivity to Islamic perception about interest earning, large family size and high unemployment of mature and educated dependents cause household's savings to be low. So it is recommended that govt. needs to launch employment-generation based projects in rural areas along with incentives packages to private sectors to extend banking facilities in rural areas, particularly Islamic banking services as well as proper population planning to control population growth. This will induce large number of small saver to develop banking habits and thus make savings more productive rather than keeping as idle cash balance or purchase of jewelry or real estate.
\end{abstract}

\section{Introduction}

Savings are the difference between income and consumption. Savings, being leakages from the circular flow of income, is that part of income which is not consumed. "The decision about how much to save and how much to spend

1 Lecturer, Institute of Management Sciences Peshawar and M.Phil Scholar, Preston University Islamabad.

2 Professor $\mathcal{E}$ HoD Economics, Preston University Islamabad Campus.

3 Assistant Professor, Institute of Management Sciences

4 Assistant Professor, Preston University Islamabad 
though are the two sides of the same coin but are very significant in applied sense". Savings can be made be different economic agents such as household, corporation and government. (Samulson).

National savings is the key determinants of long investment prospects of the country, and plays dominant role in economic growth and development. Pakistan has been trapped in low savings rates even if compared to similar income groups' e.g. highest saving rate of $21.3 \%$ in fiscal year 1971 which is much lower to its similar income counterparts. (State Bank of Pakistan, Govt. of Pakistan, 2007-08).

Pakistan has been facing severe savings - investment gap which has implications for low growth performance over the period e.g. Total investment to GDP ratio averaged $21.1 \%$ during fiscal year 2005-2009 as against total savings to GDP ratio $16.2 \%$ in the same period. Clear inspection of the facts reveals that the real cause of the savings - investment gap is the low savings rate even compared to the regional countries at same income level. (State Bank of Pakistan, Govt. of Paklstan, 2008-09).

Household savings, being a major component of the national savings, has even shown dismal performance over a number of years. Therefore it is important to investigate causes of dismal performance at micro level in particular and at macro level in general. This paper investigates the issue at micro level for the rural areas of Karak.

\section{Literature Review}

(Husain, 1995) compared the trend in private saving in Pakistan with Southeast Asian economies during 1970-93 using co-integration techniques. He confirmed financial development measured by financial deepening as an important determinant of private saving along with demographic change.

(Khan, Hasan, \& Malik, 1992) investigated main factors which influence savings rate from 1959-88. The main variables include per capita income, real interest rate, terms of trade, growth rate of real income, dependency ratio, openness of economy and foreign capital inflow. This study found a strong and significant impact in case of per capita income, real interest rate, and foreign capital inflow and dependency ratio.

(Kazmi, 1993) investigated aspects of saving rates differentials in India and Pakistan for the period of 1960-88. He concluded that almost 50\% differences in the savings rates of India and Pakistan is due to level of human devel- 
opment and demography. Import ratio and defense expenditures significantly differentiate savings rate in both said countries. He, however, cautioned that these conclusions should be taken carefully because values of co-efficient changes with changes in specification and estimation techniques.

(Ahmad, Atiq, Alam, \& Butt, 2006) examined household savings behaviors for Pakistan for the period of 1972-2003. He discovered short run and long run mechanism of the function using Johansen - Juselius co-integration techniques. He concluded that inflation rate and demographic variables negatively affect household savings whereas income, interest rate and growth have positive significant effect on household savings. He also confirmed that substitution effect dominates income effect and public savings crowed out private savings.

(Khan, Asmaullah, \& Wahid, 2009) estimated household's savings function for three rural areas of District Karak. They confirmed that household disposable income and support ratio is the major income. They concluded that land ownership and livestock have significant negative effect on the household savings in the Tehsil Takhti-e-Nasrati and Karak which are due to the dry hilly land structures. They explored that female household head save more than male household head except Tehsil Takhi-e-Nasrati Tehsil.

Though there are a lot of studies on household savings behavior at macroeconomic level but less attention is paid to the micro foundations of the issues particularly rural areas are ignored though our larger population percentage is living in the said area. So it is vital to assess major determinants of household's savings in the rural Karak and most importantly, to identify those factors which can induce people to put their small savings in financial institutions. This paper is an extended attempt to analyze savings behavior while modifying (Khan, Asmaullah, \& Wahid, 2009) work to take into account for more factors for instance, treatment of underlying statistical assumptions of the models and developing various functional forms of regression with important theoretical variables. This paper will provide useful information for policy making on the part of the govt.

\section{Research Methodology}

Methodology of this paper is based on (Khan, Asmaullah, \& Wahid, 2009) empirical work. We have modified their function for including more variables and its function form. Theory postulates that household's savings (HS) is the positive function of income (Y), negatively related to family size [(Khan, Asmaullah, \& Wahid, 2009)]. The nature of business can also affect household's 
savings (HS) e.g. self business naturally leads to a bit more savings than other forms of business. The level of education of the household's head may also account for more savings as compared to illiterate one. There can be several reasonable explanations like education level has a positive impact on the earning abilities which in turn results in more savings, secondly the more education of household's head means more consciousness which implies more saving for the future unforeseen events. The large number of dependents in a household (D) means more consumptions and hence less savings. The mathematical form of the function used is given as:

$H S=f(\log y, Z, D B, E, D)$

Where HS = household's savings, logy = Household's income, $\mathrm{Z}=$ family size, $\mathrm{DB}=$ Dummy variable for nature of business, $\mathrm{DB}=1$, if self business and $\mathrm{BD}=0$, if otherwise. $E$ = years of schooling of household's head, $\mathrm{D}=$ No of dependents in a household. Total of one hundred households were interviewed using simple random sampling techniques and various forms of the function (1) have been estimated to avoid major economic issues like heteroscedasticity and multicollinearity. For detection of heteroskedasticity, The Brush - Pagan LM test has been used. (Breusch \& Pagan, 1979). The most plausible results are obtained using Ordinary Least Square (OLS) and Weighted Least Square (WLS).

\section{Results and Discussion}

Table No. 01 shows that household income is the main determinant of the household's savings and the marginal propensity, after adjusting for heteroscedasticity where necessary, ranges from $19 \%$ to $32 \%$ which is a reasonably good savings rate at rural level. The instance need is of developing a proper mechanism for pooling and mobilizing it through formal institutions as most of the households keep their savings as just in cash form (Table No. 02). The extension of banking network and improvement in education in the area would accelerate fund mobilizations from the large pool of small savers. Though, education is important for banking habits, the banking facilities and its network by itself plays important role to channelize savings (See Table No. 03).

Large family size has been an economic issue in Pakistan in general and in rural areas in particular. The current studies highlight that family size negatively affects household's savings rate (Table No. 01). The Table No. 04 gives family size and average per month savings distribution. It clearly shows that low family size corresponds to high average per month savings and vice versa. 
Table 01: Estimated Results of function (1) using various forms

\begin{tabular}{|c|c|c|c|c|c|c|c|}
\hline Variables & OLS & WLS & WLS & WLS & OLS & WLS & OLS \\
\hline Constant & -0.24 & -0.37 & $-0.01^{*}$ & -0.13 & -0.25 & $-0.05^{*}$ & $-0.23 *$ \\
\hline Logy & $0.31 * *$ & $0.21^{*}$ & $0.19^{*}$ & $0.27^{*}$ & $0.22^{*}$ & $0.32 *$ & $0.24^{*}$ \\
\hline Z & & $-0.27 * * *$ & & & $-0.56 * *$ & & $-0.24^{*}$ \\
\hline $\mathrm{DB}$ & & & $1.23^{*}$ & & & $2.33^{*}$ & \\
\hline E & & & $2.34^{* *}$ & & & $10.01^{*}$ & $9.09^{*}$ \\
\hline $\mathrm{D}$ & & & $-0.21 *$ & $-1.31^{*}$ & $-2.4^{*}$ & & \\
\hline $\mathrm{R}^{2}$ & 0.33 & 0.35 & 0.37 & 0.21 & 0.30 & 0.32 & 0.31 \\
\hline Adjusted $\mathrm{R}^{2}$ & 0.31 & 0.34 & 0.31 & 0.23 & 0.29 & 0.24 & 0.29 \\
\hline $\mathrm{F}$ & $45.09 *$ & $100.002^{*}$ & $134.11^{*}$ & $99.09 *$ & $89.01^{*}$ & $120.02^{*}$ & 123.23 \\
\hline \multicolumn{8}{|c|}{ Source: Survey data from 100 Household's in Karak } \\
\hline
\end{tabular}

Education, measured as years of schooling of a household's head, has positive impacts on increasing household's savings (see Table No. 01). The economic justification is straight forward because high education increases probability of getting a good job with high income so more savings and vice versa.

Table 02: Household's Percentage holdings of Savings in different Liquid forms

\begin{tabular}{|l|c|}
\hline Liquid Forms & Percentage of Household (\%) \\
\hline Cash & 61 \\
\hline Banks & 9 \\
\hline Land Purchase & 8 \\
\hline Jewlary & 10 \\
\hline Others & 12 \\
\hline
\end{tabular}

Source: Survey Results

The number of dependent means non-earning members of the households. These non-earning workers consume goods and services which increase household's spending and thus decrease the ability to save. These dependent can be classified age-wise as in Table No. 05 which includes the average numbers of old-age members and youth age members who's education has been completed but still remain dependent. 
Table 03: Houshold's Response to keeping cash instead of using banking facilities (\%)

\begin{tabular}{|ll|}
\hline Don't know much about banking business & 12 \\
\hline Low Banking Network & 58 \\
\hline Because of Interest is forbidden in Islam & 25 \\
\hline Other issues & 5 \\
\hline
\end{tabular}

Source: Survey Data.

Table 04: Family Size distribution with corresponding Average savings per month - Rs

\begin{tabular}{|l|c|c|}
\hline Family & Percentage & Average Savings per Month - Rs \\
\hline $2-4$ & 23 & 1991.01 \\
\hline $5-7$ & 37 & 1881 \\
\hline 8 and above & 40 & 1334 \\
\hline
\end{tabular}

Source: Survey Data.

Table 05: Average Number of Dependents per Family

\begin{tabular}{|l|l|}
\hline Below 15 Years & 3.3 \\
\hline 15 Years to 24 Years & 5.1 \\
\hline 50 Years and Above & 2.7 \\
\hline
\end{tabular}

Source: Author's Calculation from Survey Data

The number of dependent means non-earning members of the households. These non-earning workers consume goods and services which increase household's spending and thus decrease the ability to save. These dependent can be classified age-wise as in Table No. 05 which includes the average numbers of old-age members and youth age members who's education has been completed but still remain dependent.

\section{Conclusions and Recommendations}

Though income has positive impacts on household's savings, family size and number of dependent members bear negative impacts whereas education measured as years of schoolings of household's head and ownership of private business accelerates household savings but still marginal propensity to save ranges from $19 \%$ to 32 percents. The low savings rate in our rural areas combined with less mobility of savings into investments is, based on inference of this study, due to the habit of high cash holdings, purchases of jewelry and real 
estate which though add to the family wealth but remains unproductive in the true economic sense. The main reason is not education as commonly presumed rather less excess to banking network and Islamic belief about interest based earnings on such income are the main factors that hinders the transformation of these savings into capital. Another striking cause is increased numbers of dependents per family particularly those who have got secondary and higher education and are still jobless. All these factors, lead to low performance in generating and mobilizing household's savings into more productive channels. So it is recommended, in the light of the study, that govt. needs to expand employment-generation based projects in rural areas and launch proper incentive packages to the private sectors to expands banking network particularly Islamic banking system so that larger numbers of small savers could be attracted and their small savings could be put into productive channels. This would increase the domestic financial resources needed for development sector and thus would be helpful to reduce dependence on the international financial organizations too.

\section{References}

Ahmad, M. H., Atiq, Z., Alam, S., \& Butt, M. S. (2006). The Impact of Demography, Growth and Public Policy On Household Savings: A Case Study of Pakistan. Asia-Pacific Development Journal , 57-71.

Husain, A. M. (1995). Long Run Determinants of Private Saving Behaviour in Pakistan. The Pakistan Development Review, 1056-1066.

Kazmi, A. A. (1993). Natioanl Savings Rates of India and Pakistan: A Macroeconometrics Analysis. Pakistan Development Review.

Khan, A. H., Hasan, L., \& Malik, A. (1992). Dependency Ratio, Foriegn Capital Inflow and the Rate of Savings in Pakistan. Pakistan Development Review, 843-856.

Khan, Z., Asmaullah, \& Wahid, F. (2009). Intra Rural Regional Difference in Household Savings: Emprical Evidence From three rural Areas of Karak District Karak (Pakistan). Abasyn University Journal of Social Sciences, 74-78.

Samulson, P. A. Economics. (3rd, Ed.)

State Bank of Pakistan, Govt. of Pakistan. (2007-08). Trends in Financial Savings, Financail Stability Review. Islamabad: State Bank of Pakistan.

State Bank of Pakistan, Govt. of Paklstan. (2008-09). Trends in National and Financial Savings, Financial Stability Review. Islamabad: State Bank of Pakistan. 